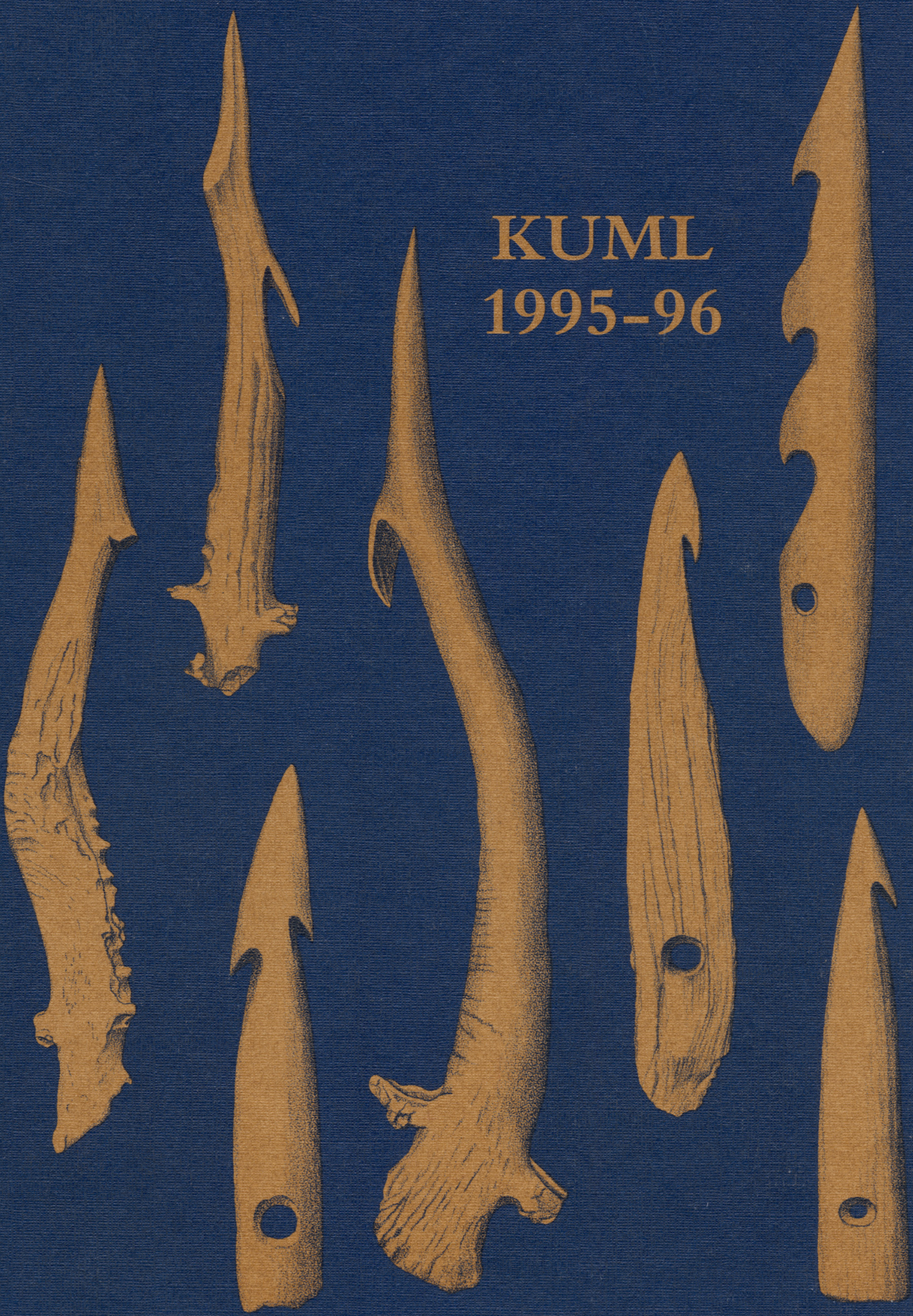


KUML 1995-96 


\section{KUML 1995-96 \\ Årbog for Jysk Arkæologisk Selskab}

With summaries in English

I kommission hos Aarhus Universitetsforlag, Århus 
Redaktion: Hans Jørgen Madsen og Jesper Laursen

Omslag: Jorgen Mührmann-Lund

Grafisk tilretteloggelse: Elsebet Morville

Tryk: Narayana Press

Skrift: Bembo 12/13

Papir: $115 \mathrm{~g}$ Arctic Silk

Copyright (C) 1997 by Jysk Arkcoologisk Selskab

ISBN 87-7288-592-0

ISSN 0454-6245 


\section{Indhold/Contents}

Palle Friis: Poul Kjærum. Worsaae-medaillen 16. maj 1996 ............................. 7

Poul Kjærum. Worsaae medal ........................................................ 10

Ole Høiris: Kampen om stenalderen. Antropologiske bud på vor oprindelse

i fortid og nutid ..................................................................................... 13

Fight over the Stone Age ................................................................. 44

Søren H. Andersen: Ertebølleharpuner og spækhuggertænder. Aspekter af marin fangst i Ertebølletid ............................................................. 45

Ertebølle harpoons and killer whale teeth. Aspects of marine hunting

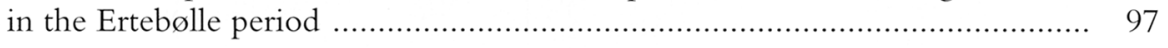

Klaus Ebbesen: Terningspil i yngre stenalder …........................................ 101

Dice and Dicing in the Stone Age ............................................... 111

Carsten Korthauer: En ældre romertidsgrav med guldmønt fra Jylland - samt nogle iagttagelser om møntomløb og -funktion i jernalderens Danmark ......... 113

An Early Roman Iron Age Grave containing a Roman Gold Coin ............. 133

Poul Mikkelsen og Lis Helles Olesen: Vendeldiget ........................................... 135

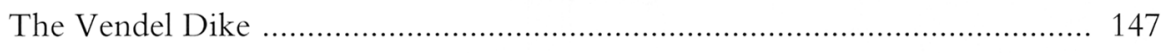

Jens Jeppesen og H.J. Madsen: Trækirke og stormandshal i Lisbjerg ...................... 149

A Wooden church and Big Man's Hall at Lisbjerg ..................................... 169

Mogens Rud: En skjult sandhed i Bayeux-tapetet? Hvad skulle Harald

Godwinson i Normandiet? ....................................................... 173

A hidden Revelation in the Bayeux tapestry? What was Harald

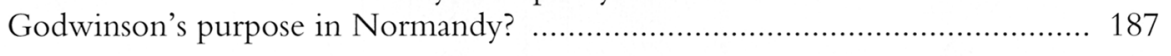

Hans Skov: Udgravningerne ved Aarhus Katedralskole i 1994-95 ....................... 189

Excavations at Aarhus Cathedral School in 1994-95 .................................. 206

Jette Linaa Larsen: Skår i tusindtal - keramik fra Torvet i Horsens

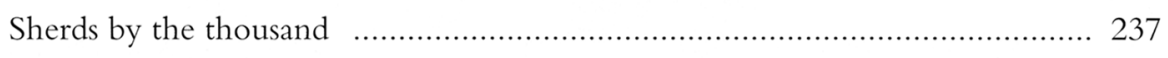

Jens Andersen: Jydepotter fra Brønderslev ................................................. 239

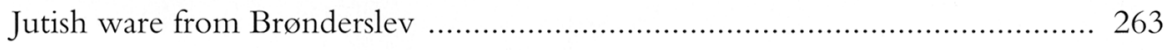

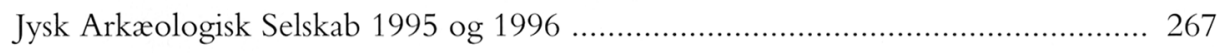




\title{
En skjult sandhed i Bayeux-tapetet? \\ Hvad skulle Harald Godwinson i Normandiet?
}

\author{
Af MOgens Rud
}

Bayeux-tapetet - et af Frankrigs største historiske og kulturhistoriske klenodier - er et mere end 900 år gammelt, broderet vægtæppe med en skildring af, hvorledes Normandiets hertug Vilhelm i 1066 erobrede England. I dag er det virkningsfuldt udstillet i Centre Guillaume le Conquérant nær domkirken i den lille normanniske by Bayeux.

Den kortest mulige beskrivelse af værket er den ældste kendte henvisning til det, nemlig Bayeux-katedralens inventarliste fra 1476, hvor der står: " ... desuden en meget lang og meget smal strimmel loerred, broderet med figurer og inskriptioner, der skildrer Englands erobring." Der er virkelig tale om en meget lang strimmel lærred - over 70 meter, eller to gange Rundetårns højde.

Omtalen fortsætter: "Den honges rundt langs kirkens skib ved relikviefesten (1. juli) og $i$ de folgende otte dage." (Bertrand 1966, 18-19.)

At noget så forgængeligt som et broderi overhovedet er bevaret siden tidlig middelalder, skyldes vel dels denne begrænsede brug, dels at det med sine beskedne materialer - farvet uldgarn og groft hørlærred - ikke har været værd at røve under opstande og krige.

Ordet tapet betyder oprindelig "tæppe" - i dette tilfælde vægtæppe, et almindeligt inventar i kirker og fyrstepaladser på den tid. Bayeux-tapetet er imidlertid enestående i sin art, både på grund af dets billeder af en række historiske begivenheder, og fordi disse er "tekstet". Det består af en hovedfrise med selve den kronologiske skildring, forsynet med korte, latinske tekster. Foroven og forneden løber en dekorativ bort, udfyldt med skråbjælker, stiliserede planter, fabeldyr, små scener fra dagliglivet, og visse steder med motiver, f.eks. fra Æsops fabler, der kan tolkes som symbolske referencer til handlingen (Bernstein 1986).

Forskellige træk tyder på, at tapetet er fremstillet i England (Rud 1994, 10 og 73), måske i Canterbury, hvor der var en særlig tradition for dekorativt broderi, og at det er sket kort efter, at hertug Vilhelm (Erobreren) havde sejret ved Hastings 1066. Det menes udført på bestilling af 
Vilhelms halvbroder, biskop Odo af Bayeux, der selv deltog i slaget og som optræder flere steder i tapetets skildring. Det er formodentlig færdiggjort til indvielsen af Odos nye domkirke i Bayeux i 1077.

\section{To forskellige versioner}

Historieskrivning er ikke nogen eksakt videnskab. Tværtimod. Hvornår er en kilde til en historisk begivenhed sand? Hvor tit har man ikke set tingene fremstillet - $\mathrm{i}$ tekst eller billeder - på en sådan måde, at beskrivelsen fremstod til forherligelse af magthaveren og derved også til gavn for ophavsmanden? Et historisk dokument kan f.eks. også have til opgave i moralens navn at påpege en konsekvens af en bestemt handling - uanset om denne er en fastslået kendsgerning eller ej.

Sådan et dokument er Bayeux-tapetet. Det illustrerer en række velkendte historiske begivenheder, men fortæller også - uden at det siges direkte i de ledsagende tekster - hvordan det går, når en mand bryder sin hellige ed: han rammes ubønhørligt af skæbnen, her i form af en voldsom død, og i dette tilfælde også med et epokegørende magtskifte til følge, da Englands dansk-angelsaksiske herredømme blev afløst af et fransk-normannisk styre.

At den mægtige, engelske jarl Harald Godwinson foretog en skæbnesvanger rejse til Normandiet i 1064 er velkendt - men hvad er sandheden om denne færd, hvad var dens virkelige formål? Den første tredjedel af tapetets lange billedrække er helliget denne rejse, hvis følge to år senere blev det skelsættende slag ved Hastings, som åbnede vej for hertug Vilhelm til Englands trone og skaffede ham tilnavnet "Erobreren".

Lad os først se på, hvad Bayeux-tapetet i sig selv fortæller beskueren, inden vi lader samtidens krøniker supplere med deres skildringer af begivenhederne.

I tapetets allerførste scene (fig. 1) ses under teksten EDVVARD REX den aldrende engelske kong Edward, kaldet "Bekenderen", siddende på sin tronstol med scepter i hånd og krone på hovedet; det er tydeligt, at han taler indtrængende til de to stående mænd, som må være Wessex' jarl Harald Godwinson og en ledsager. Harald var søn af Knud den Stores magtfulde jarl Godwin, og hans søster Edith var gift med Edward. Harald og kongen var altså svogre. At der er tale om Harald, ses i næste scene, som har overskriften VBI HAROLD DUX ANGLORUM ET SVI MILITES EQVITANT AD BOSHAM "Hvor Harald, englændernes jarl, og hans mænd rider til Bosham" (hvor jarlen havde sin gård). Det fremgår ikke, hvad kongen har meddelt Harald.

Efter at have knælet ved - eller i - en kirke og indtaget et måltid går jarlen med sit følge om bord på et skib og står til søs. Skal de over Kanalen til Normandiet eller blot på en lokal kystfart? De medbringer både 


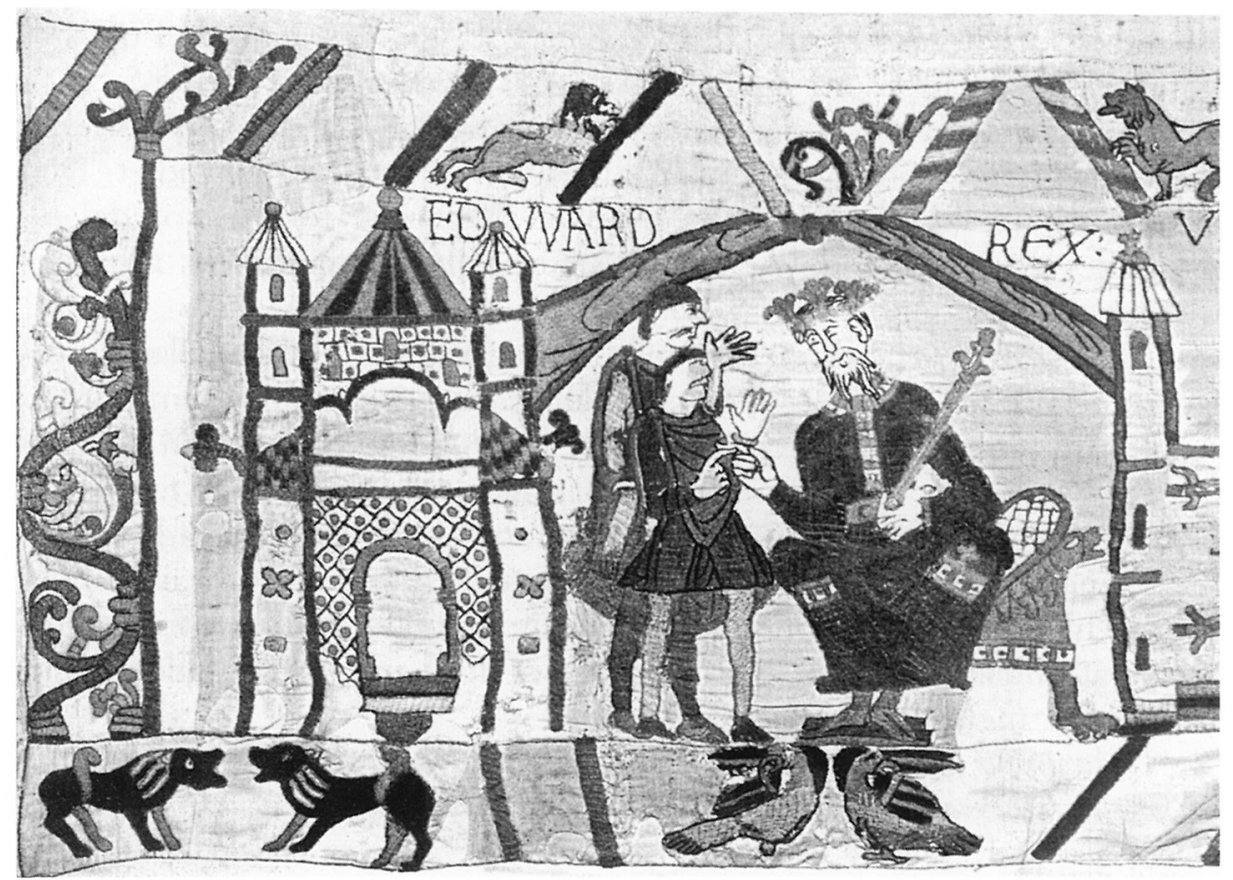

Fig. 1. Bayeux-tapetets første scene: Kong Edward i ivrig samtale med sin jarl, Harald Godwinson, og en ledsager før den skæbnesvangre sørejse.

The first scene of the Bayeux Tapestry. King Edward in lively conversation with his earl, Harald Godwinson, and with a companion before the fatal journey.

hunde og en jagtfalk - er det gaver til Vilhelm, eller skal ekspeditionen camoufleres som en jagtudflugt? Tapetet skildrer derefter tydeligt nok, at selskabet straks ved en landgang i Frankrig bliver pågrebet af grev Wido (Guy) af Abbéville og ført til dennes borg i Beaurain. Her bliver Harald afhørt. Der ankommer budbringere fra Widos overherre, hertug Vilhelm, som byder, at jarlen løslades. Wido fører derefter selv englænderne til mødet med hertugen. Tapetet skildrer, at Harald nu gør rede for sit xrinde eller sin situation over for Vilhelm, mens han tilsyneladende peger mod en af de bevæbnede mænd bag sig. Det følgende optrin, "Hvor en klerk og Ælfgyva”, er ikke omtalt i nogen krønike; det samme gælder jarl Haralds redningsdåd i kviksandet ved Mont Saint Michel undervejs til en straffeaktion mod grev Conan af Bretagne. Da denne aktion var vel overstået, "gav Vilhelm Harald våben", dvs. gjorde ham reelt til sin vasal (Rud 1994, 50-52).

Efter at Harald ifølge både indskrift og billede i tapetet havde aflagt ed til hertug Vilhelm, vendte jarlen hjem til England - "og kom til kong Edward". Denne sidste scene før skildringen af kongens død og bisættelse er et nøjere studium værd, og det vil vi vende tilbage til. Resten af 
tapetet viser, at Harald efter Edwards død lader sig vælge til Englands konge; Vilhelm invaderer England, og Harald falder ved Hastings.

Ovenstående er, hvad der umiddelbart kan aflæses af tapetets skildring af Haralds rejse og hans ophold hos hertug Vilhelm i Normandiet. Den traditionelle tolkning af tapetets motiver støtter sig for en stor del til, hvorledes de pågældende begivenheder er skildret i samtidens normanniske krøniker.

Tidligt i 1070'erne skrev den unge hertug Vilhelms hofkapellan, Guillaume de Poitiers, værket "Gesta Guillelmi ducis Normannorum et regis Anglorum" (her citeret efter Albrectsen 1980). Heri skildrer han de samme begivenheder, som munken Guillaume de Jumiège få år for havde beskrevet i sin krønike "Gesta Normannorum Ducum", sandsynligvis med kendskab til dennes værk. Jumiège fortæller, at kong Edward sender Harald til Normandiet for at støtte hertug Vilhelm som den fremtidige konge af England. Poitiers' version er mere detaljeret, og ordlyden er lidt anderledes, men indholdet er det samme:

"Omtrent på samme tid gav kong Edward af England sit arveløfte til Vilhelm en yderligere bekraftelse, den Vilhelm, han satte pris på, som var det hans egen broder eller søn. I god tid ville han lade ham tilgå viden om dødens almagt, den som denne mand, der gennem et helligt liv sigtede efter det himmelske kongerige, nu så norme sig endeligt. For at bekrafte sin anelse med ed sendte han Harald, den fornemste af alle sine mand gennem rigdom, poster og magt, den Harald, hvis broder og nevo tidligere var stillet som gidsler $i$ sikkerhed for denne samme arvefolge. Det var med klogt overlag, han valgte ham, for hans rigdom og indflydelse kunne tvinge englonderne til at underkaste sig, hvis de efter deres scedvanlige upålidelighed og vagelsind hellere ville ordne sagen efter deres eget hoved. Da Harald uden toven gik $i$ gang med denne opgave, landede han efter at vare sluppet igennem den farefulde overfart på strandbredden $i$ Pontieu, hvor han faldt $i$ handerne på grev Wido (fig. 2). Da han med sit folge var taget til fange, satte man ham i fangsel, hvad denne mand betragtede som en ulykke storre end at have lidt skibbrud. Opfindsom begcerlighed har hos nogle af gallerfolkene fundet på en modbydelig skik, barbarisk og mod al kristelig retfoerd: man loggger falder for de magtige og rige, sparrer dem inde i fangsler, udsatter dem for overgreb og pinsler. Efter at man med forskellige hjemsøgelser har bragt dem noer dodens rand, slipper man dem ud af fangslet, tit for at scelge dem til en stormand.

Så snart hertug Vilhelm havde hørt, hvad der var hoendt for Harald, sendte han omgående budbringere og fik ham ud af fangslet både med bonner og trusler. Han drog ham $i$ mode og modtog ham med hoeder. Han takkede Wido på passende vis, overgav anselige landstrakninger, meget gods, store pengegaver $i$ sølv til denne mand, der havde gjort sig fortjent dertil, og som uden at vare tvunget af belonning eller vold selv personlig havde bragt en fange til borgen $i \mathrm{Eu}$ og afgivet denne mand, som han efter forgodtbefindende havde kunnet pine, drabe eller salge. Han forte under store aresbevisninger Harald ind $i$ Rouen, hovedstaden ifyr- 

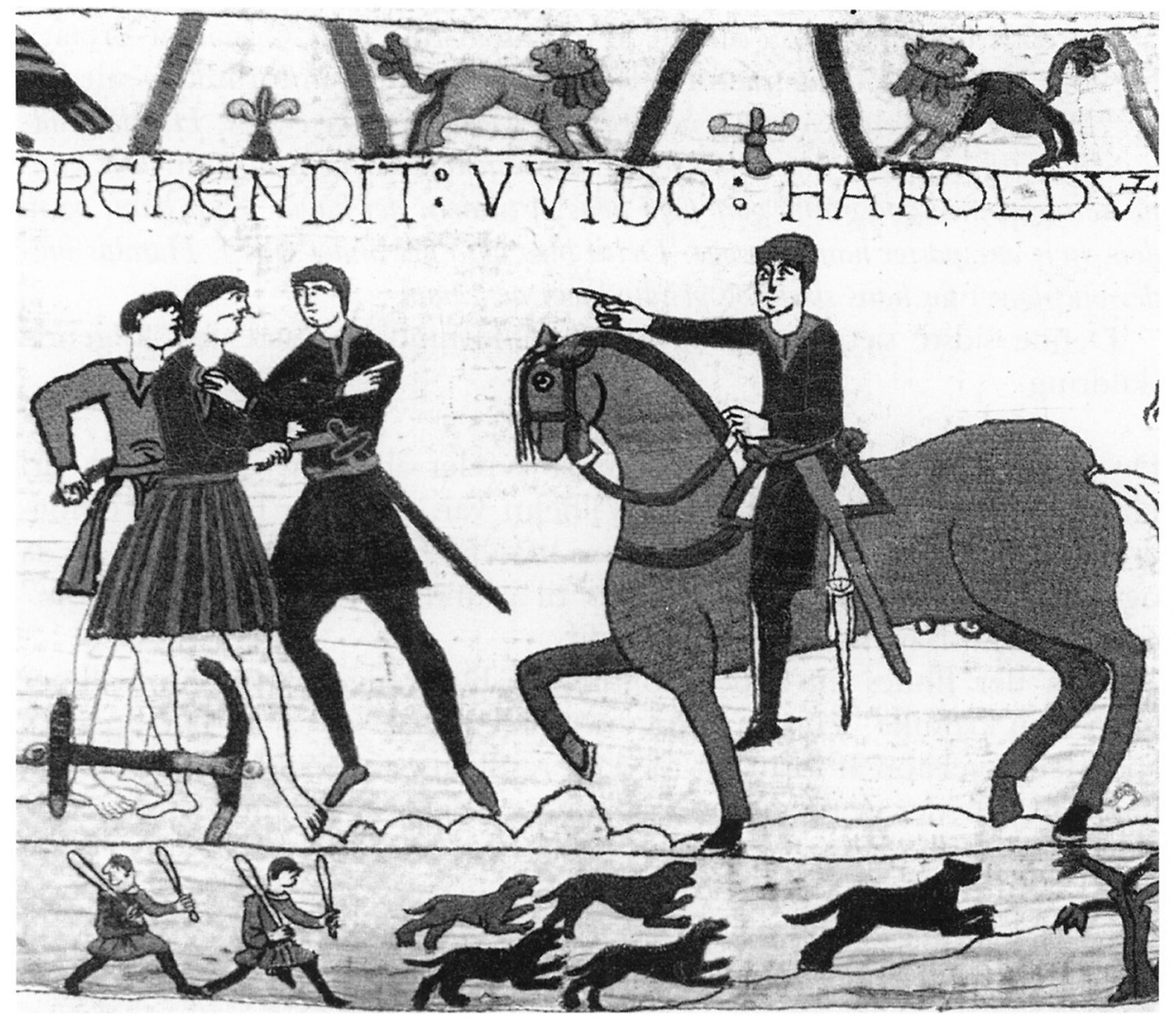

Fig. 2. Straks efter sin landgang i Frankrig bliver Harald Godwinson, der endnu ikke har fået sine hoser på igen efter at have vadet $\mathrm{i}$ land, taget til fange af den lokale landsherre, grev Wido. Denne dramatiske begivenhed skildres også i samtidige krøniker.

Immediately after landing in France Harald Godwinson, who has not yet put on his trousers after wading ashore, was captured by the local lord, Count Wido. This dramatic event is described in contemporary chronicles as well.

stedommet, hvor en udstrakt gastfrihed med mangfoldige adspredelser på den behageligste måde bragte hans geester på fode efter alle turens anstrengelser. Hertugen gloedede sig over at have en så beremt gast hos sig sendt af hans kareste slagtning og ven og håbede, at han $i$ gasten ville finde en trofast mellemmand mellem sig og englonderne, blandt hvilke Harald havde hojest rang efter kongen. Da et råd var trådt sammen $i$ Bonneville, tilsvor Harald hertugen ... at så lange kong Edward endnu måtte leve, ville han ved det engelske hof vare hertug Vilhelms udsending, og han ville bestrabe sig for, så lange han kunne, gennem sine råd og med sin støtte at lade ham efter Edwards dod befaste $i$ besiddelsen af Englands trone. ... Da hertugen havde taget Harald til vasal, overdrog han ham på hans krav og for edsaflaggelsen alle de jorder, som tilhorte ham. Man regnede med, at der ikke ville gå lang tid, for Edward, der nu var syg, dode ..." 
Herefter følger en lang omtale af felttoget mod grev Conan af Bretagne, som Harald og hans mænd deltog i, og beretningen fortsæetter således:

"Da han (Vilhelm) igen var vendt hjem, boede hans kare goest, Harald, endnu nogen tid hos ham, indtil han sendte ham hjem belosset med gaver. Det kunne hertugen med god grund gore med hensyn til den, der havde sendt ham, og til den, hvis ceresposter han ville oge. Dertil blev også det andet gidsel, Haralds brodersen frigivet for hans skyld og vendte hjem med ham ..."

Denne sidste sætning er interessant i forbindelse med den følgende skildring.

De to næunte, normanniske forfattere tvivler åbenbart ikke på, at jarl Haralds formål med besøget hos Vilhelm var, på kong Edwards opfordring at love støtte til hertugen i hans krav på Englands krone. Det er da også denne fremstilling, som ligger til grund for nutidens "officielle" udlægning af Bayeux-tapetets indhold.

Men der findes en anden forklaring. Den engelske munk Eadmer giver i sin krønike "Historia Novorum in Anglia" fra ca. 1115 en ganske anderledes version af formålet med og resultatet af Haralds rejse, om end flere enkeltheder er de samme - hvilket til en vis grad understøtter troværdigheden:

"Kort efter at Harald havde overtaget Wessex efter sin far Godwins dod 1053 bad han kongen om tilladelse til at rejse til Normandiet for at fa frigivet sin broder og sin nevø, der blev holdt dér som gidsler, og derefter bringe dem hjem. Kongen sagde til ham: 'Jeg vil ikke have nogen del i dette; men for ikke at give dig indtryk af et onske om at hindre dig giver jeg dig tilladelse til at rejse, hvorhen du vil, og at se, hvad du kan gore. Men jeg har en forudanelse om, at det kun vil lykkes dig at bringe ulykke over hele kongeriget og over dig selv. For jeg ved, at hertugen ikke er så enfoldig, at han overhovedet er tilbøjelig til at overlade dem til dig, med mindre han forudser, at han ved at gore det kan sikre sig selv en eller anden stor fordel.' Harald, der stolede mere på sin egen dommekraft end på kongens, gik om bord på et skib, idet han tog med sig sine rigeste og mest hadervardige mand, udstyret med en fornem forsyning af guld, solv og kostbare klader. Men snart blev havet stormfuldt, og de ombordvarende blev radselsslagne, da skibet blev kastet omkring af de magtige bolgers kraft. Til sidst blev det med alt, hvad der var om bord, drevet ind i en flod i Pontieu, kaldet Maye. Dér blev det i overensstemmelse med lokal skik beslaglagt af landsherren, og mandene om bord blev sat under streng arrest.

Harald blev således holdt fangen. Men det lykkedes ham at bestikke en af almuen med et lofte om belonning og sende ham hemmeligt til hertugen af Normandiet for at rapportere, hvad der var hoendt ham. Hertugen sendte derpa omgånde budbringere til Pontieus hersker og meddelte ham, at hvis han ønskede at bevare hans venskab i fremtiden, som han havde haft det hidtil, skulle Harald 
og hans mand sendes til ham så hurtigt som muligt, og det uden nogen anklage imod ham. Den anden nogtede at lade sin fange gå, hvorpa han modtog et nyt, bestemt budskab om, at han skulle sende Harald. Hvis ikke, kunne han vare sikker på, at Vilhelm, Normandiets hertug, ville komme bevabnet til Pontieu for at satte ham fri. Han sendte derfor nu Harald og hans moend af sted, men ikke uden forst at have berovet dem alle de mest voerdifulde ejendele, de havde bragt med sig. På denne måde kom Harald til Vilhelm og blev modtaget med hader.

Da Vilhelm havde fäet at vide, hvorfor Harald var rejst fra England, svarede han, at hans mission afgjort ville lykkes - hvis ikke, ville det vere hans egen fejl. Så beholdt han Harald hos sig $i$ nogle dage og robede $i$ tidens lob varsomt, hvad han havde $i$ sinde. Han sagde, at kong Edward, da han for år tilbage, mens de begge var unge og havde opholdt sig sammen $i$ Normandiet, havde lovet ham og sat sit ord $i$ pant på, at hvis han, Edward, nogensinde skulle blive konge af England, ville han overlade Vilhelm retten til at efterfolge ham på tronen som sin arving. Vilhelm fortsatte med folgende: 'Hvis du på din side påtager dig at stotte mig $i$ dette projekt og ydermere lover, at du ved Dover vil opfore en fast borg med en brend til min afbenyttelse, samt at du på et tidspunkt, aftalt imellem os, vil sende din soster til mig, så jeg kan give hende en af mine adelsmand til agte, og at du vil tage min datter til hustru, så vil jeg lade dig fä din nevo straks og din broder sund og rask, når jeg kommer til England for at blive konge. Og, hvis jeg med din hjalp engang sidder dér som konge, lover jeg, at du skal få alt, hvad du beder mig om, som med rimelighed kan tilstås.'

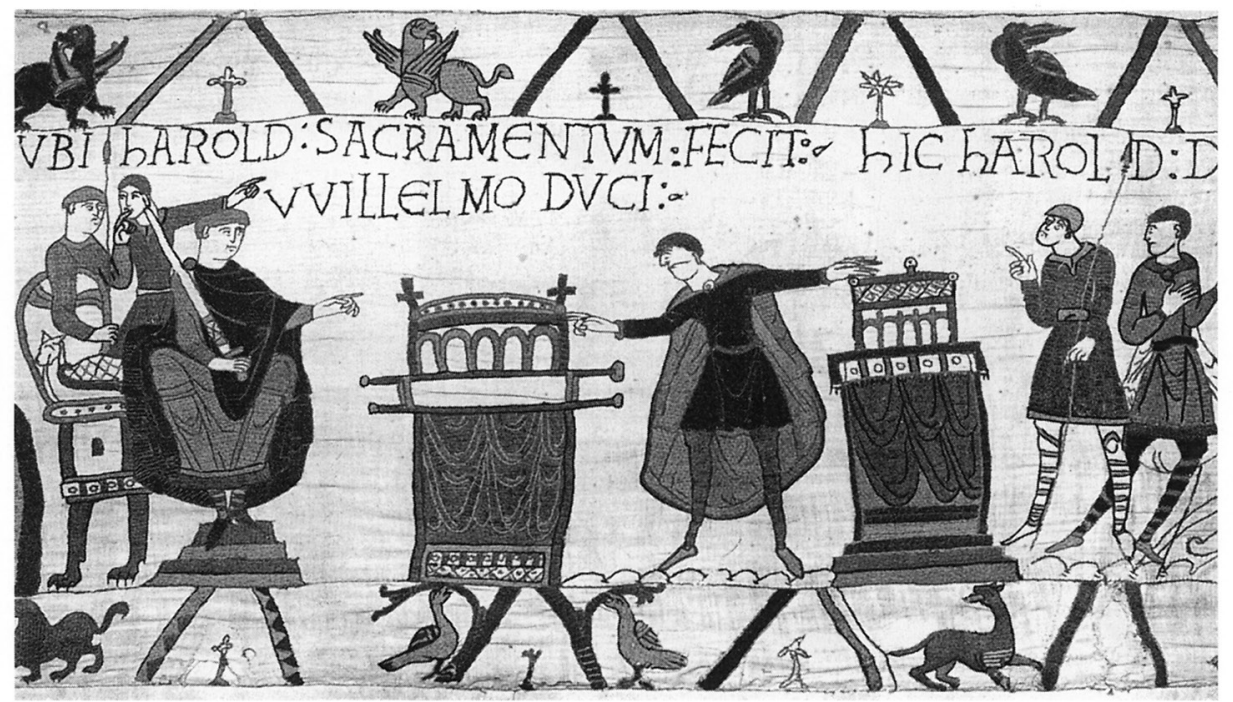

Fig. 3. Jarl Harald aflægger sin skæbnesvangre ed til hertug Vilhelm af Normandiet. Blev han presset til det, og svor han blot på skrømt?

Earl Harald swears the fatal oath of fealty to Duke William of Normandy. Was he under pressure or was he only pretending? 
$\mathrm{Nu}$ indså Harald, at der lurede fare, hvor han end vendte sig. Han kunne ikke se nogen mulighed for tilbagetog uden at gå ind på alt, hvad Vilhelm onskede. Derfor gjorde han det. For at sikre, at alt skulle vare urokkeligt bekraftet, lod Vilhelm relikvier bringe frem og lod Harald svarge ved dem (fig. 3), at han $i$ sandhed ville fuldbyrde alt, hvad de havde aftalt imellem sig, forudsat at han ikke forinden var berøvet livet, en risiko, som alle dødelige er underkastet." Antyder Bayeux-tapetets kunstner i sin gengivelse af dette optrin, at Harald svor på skrømt? Ikonografer har gjort opmærksom på, at mens jarlen korrekt lægger to fingre på det ene helgenskrin, "flimrer" hans venstre hånd på det andet. En agtpågivende normanner bagved peger forarget på den svigefulde hånd (Gotfredsen og Frederiksen 1987, 76). Teksten fortsætter:

"Da alt dette var gjort, tog Harald sin nevo og vendte hjem. Da han dér blev udspurgt af kongen og fortalte ham, hvad der var sket, udbrod kongen: 'Sagde jeg dig ikke nok, at jeg kendte Vilhelm, og at din rejse kunne bringe uhorte kalamiteter over dette kongerige?"”

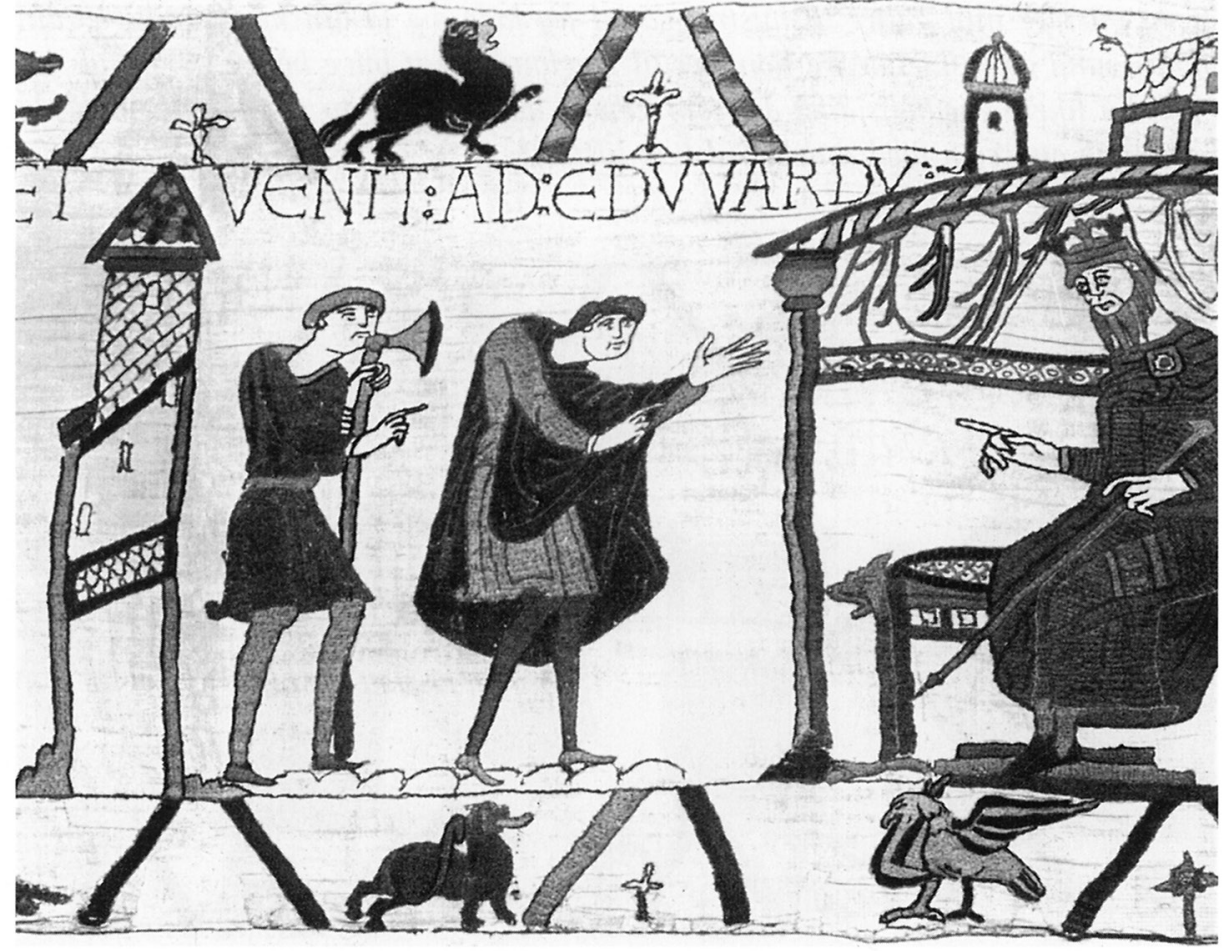

Fig. 4. Efter sin hjemkomst til England aflægger Harald rapport til kong Edward. Der er en slående forskel på situationen her og i den allerførste scene.

After returning to England, Harald informs King Edward. There is a striking difference between the situation here and in the first scene. 
Prøv nu at se på billedet af Haralds gensyn med Edward (fig. 4). Er det Englands største jarl, der stolt beretter, at han har fuldført sin mission? Og er det en konge, der tilfreds med resultatet roser sin loyale stedfortræder? Eller er det en skamfuld og ydmyg Harald, som må krybe til korset og vedstå sit aftvungne, fatale løfte til Normandiets hertug, og en vred og skuffet Edward, der syg og træt retter en dadlende finger mod sin jarl med ordene: "Hvad sagde jeg!"?

Skal vi tro, at Bayeux-tapetet er fremstillet i England og oven i købet i Canterbury, hvor Eadmer var munk, understøtter denne scene slående Eadmers version af historien.

Hvem er mest troværdig, de samtidige fransk-normanniske krønikeforfattere fra Jumiège og Poitiers, eller englænderen Eadmer, der var født få år før Englands erobring og som begyndte at skrive i 1000-tallets sidste tiår? De to krønikeskrivere fra Jumiège og Poitiers har begge kendt Vilhelm Erobreren og havde god grund til at fremstille begivenhederne til fordel for deres hertug, nu Englands nye konge. Eadmer på sin side kan under sit ophold og sine studier i Canterbury meget vel have mødt og talt med mange, der havde stået både Edward og Harald nær, og fra dem have hørt om formålet med jarlens rejse og om dens ulykkelige konsekvenser. Eadmer har næppe selv fundet på sin beretning, og med et England i normannisk magt var det vel endda risikabelt at modsige de "officielle" kilder.

\section{Gidslerne}

De to gidsler, der omtales i Poitiers' krønike, var to unge repræsentanter for den mægtige Godwin-slægt: Harald Godwinsons yngste broder, Wulfnot, og Haralds brodersøn Hakon, søn af hans ældste broder, Svend. De var som nævnt ifølge Poitiers blevet bragt til Vilhelm som sikkerhed for arvefølgen og har dengang været mindreårige drenge. Hakon kommer nu åbenbart hjem sammen med Harald. Wulfnots skæbne omtales ikke i krøniken; men senere engelske forfattere beretter, at Vilhelm beordrede Wulfnots frigivelse på sit dødsleje 1087.

Var Haralds formål virkelig at forsøge at få gidslerne frigivet, som Eadmer skriver? Var det Harald magtpåliggende at fă reddet dem hjem, før Englands stormænd utvivlsomt ville tilbyde ham kronen, når den barnløse kong Edward var død?

Efter at have gjort rede for begivenhederne omkring Godwin og hans ældste sønners landsforvisning i $1051 \mathrm{som}$ følge af en uoverensstemmelse med kongen, og deres senere forsøg på en forsoning med kong Edward, fortæller Eadmer imidlertid om selve gidselstillelsen:

"Men kongen, som var mistanksom over for Godwins listighed, vagrede sig og ville ikke slutte fred, med mindre han forst havde fäet gidsler som sikkerhed. Derfor blev Wulfnot, en søn af Godwin, og Hakon, søn af hans søn Svend, givet som 


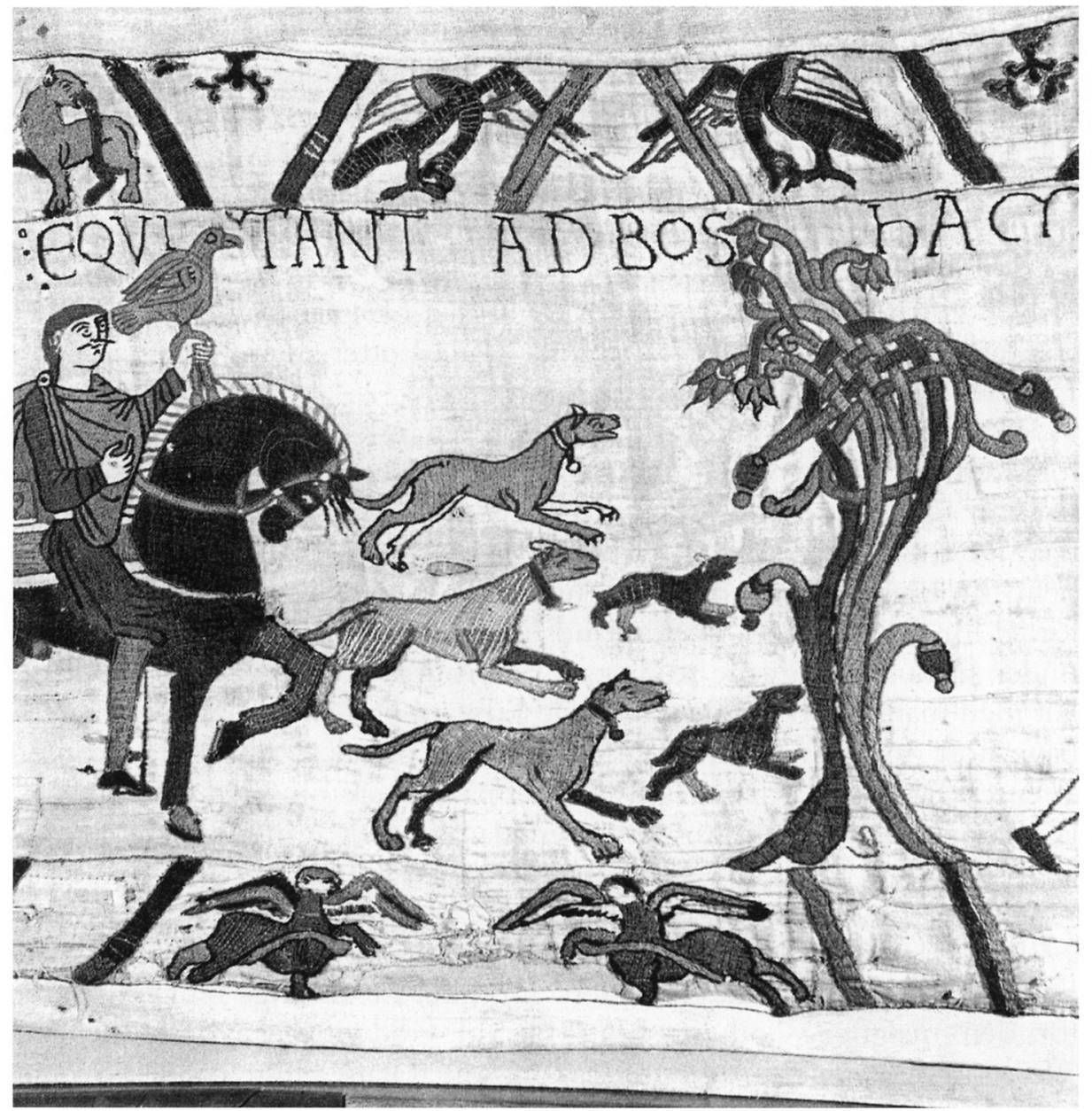

Fig. 5. Skal de to små vingede kentaurer i borten forneden diskret hentyde til Harald's sande formål med rejsen? Og skal de to fangne fugle i borten foroven gøre det samme?

Do the two little winged centaurs in the bottom border refer discreetly to Haralds real purpose with the journey? And do the two captured birds in the top border do the same?

gidsler og sendt til Normandiet under formynderskab af hertug Vilhelm, en son af Robert, søn af Richard, som var broder til kongens moder ..."

Der er altså to forklaringer også på afgivelsen af gidslerne. Enten var de stillet som sikkerhed for kong Edwards løfte til Vilhelm, eller også var de et pant på Godwins fremtidige loyalitet over for kongen. Gidslernes identitet siger os næppe noget om, hvilken forklaring der er den sande; hvad enten baggrunden var et krav fra hertug Vilhelm eller fra kong Edward, ville det være naturligt at vælge et par unge slægtninge af den mægtigste mand i England efter kongen selv. 
Hvis de normanniske krøniker taler sandt, er det rimeligt nok ikke at finde hentydning til gidslerne i Bayeux-tapetet, som utvivlsomt er et normannisk-bestilt arbejde - gidslerne spiller i den sammenhæng ingen større rolle. Men i 1979 fremsatte den amerikanske professor R.D. Wissolik en ny teori (Wissolik 1979, 69-97). På baggrund af den almindeligt anerkendte opfattelse, at tapetet blev tilrettelagt og fremstillet i det overvundne England, fremfører Wissolik den tanke, at tapetet indeholder en "kode", skjulte hentydninger, indarbejdet af tæppets håndværkere, som kun kunne forstås af engelske beskuere. Han argumenterer for, at Eadmers hidtil betvivlede troværdighed bliver revurderet, idet han påstår, at flere enkeltheder i hans "Historia" viser sig i tapetet som fordækte tegn. Mest oplagt er naturligvis den før omtalte scene, hvor den næsten krybende Harald aflægger rapport til kong Edward. Men efter Wissoliks mening optræder også selve gidslerne $\mathrm{i}$ tapetets billeder, begge to allerede i den 2. scene, hvor Harald og hans mænd rider til Bosham efter samtalen med kongen. I borten forneden ses to små, vingede kentaurer, forsynet med barnehoveder (fig. 5). Skal de mon ikke repræsentere drengene Hakon og Wulfnot og i smug hentyde til den kommende rejses formål?

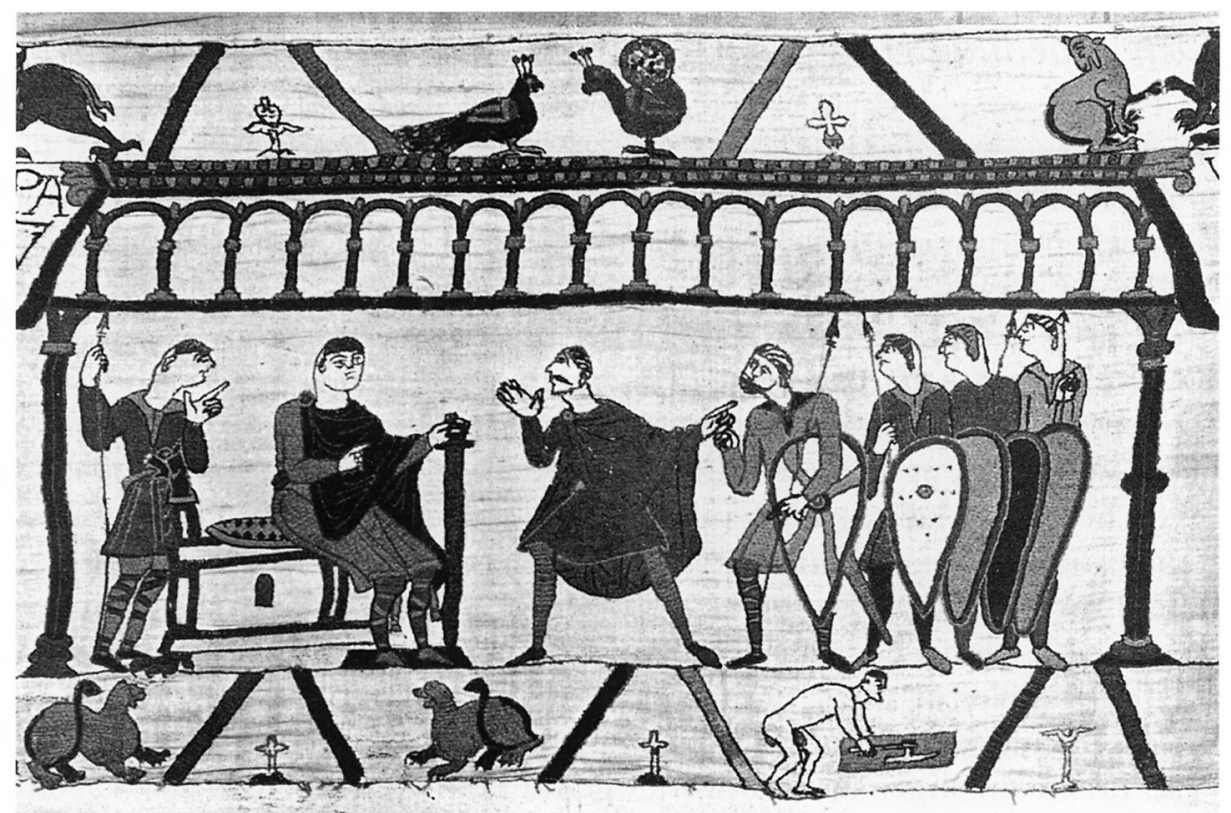

Fig. 6. Harald Godwinson fremfører sit ærinde for hertug Vilhelm i Rouen. Den forreste hirdmand, som er i nærkontakt med jarlen, skiller sig tydeligt ud fra de andre - er han gidslet Hakon?

Harald Godwinson explains his errand to Duke William in Rouen. The front retainer, who is in contact with the earl, is clearly different from the others. Is he Hakon the hostage? 
Wissolik hæfter sig derefter stærkt ved det motiv, hvor Harald over for Vilhelm gør rede for sit ærinde - ifølge traditionen: bekræfter sin konges løfte om Vilhelms arveret (fig. 6). Men Wissolik har en anden udlægning. I motivet står der bag jarlen fire bevæbnede hirdmænd. De tre er skægløse og har barberede nakker - de er tydeligvis normanner. Men den forreste, der skiller sig ud fra de andre, er en ung mand med et kort fuldskæg og med langt hår i nakken. Ingen normanner i tapetet ser sådan ud. Der er næppe tvivl om, at Harald peger netop på ham, at han vist endda berører den unge mands højre hånd. Manden holder både sit spyd og sit skjold med venstre hånd, så hans højre er fri. Er han mon ikke netop den nu ca. 17-årige Hakon, som gør tjeneste i Vilhelms hird - ham der forhandles om? spørger Wissolik.

Wissolik mener, at for de indforståede har designeren til identifikation af manden indført et ellers uforklarligt motiv i borten lige under optrinet: en skægget person, som bearbejder en svær træklods med en bredøkse. Han hugger eller hakker, et verbum, der på oldengelsk hedder haccian lydmæssigt nærmer ordet sig navnet Hakon!

Er den for langt ude? Måske; men hvad skal den skæggede hakker ellers symbolisere? Wissoliks argumenter er under alle omstændigheder tankevækkende.

\section{Den gådefulde AElfgyva}

Er Hakons mor også vist i Bayeux-tapetet? I den scene, der følger lige efter ovenstående og som er tekstet VBI VNVS CLERICVS ET ÆLFGYVA - "hvor en præst og Ælfgyva" - ses en kvinde iført lang kjortel og slør; en kronraget gejstlig træder frem imod hende og berører hendes kind med sin udstrakte højre hånd (fig. 7). I løbet af det sidste par hundrede år er der blevet fremsat mindst et dusin forskellige teorier om Ælfgyvas identitet - fra en skøge til rådighed for Harald under opholdet i Rouen til Knud den Stores længst afdøde dronning. I nogle af tolkningerne siges det, at præsten tildeler kvinden en lussing, i andre, at han giver hende et kærtegn. Hendes ranke, åbne attitude og ikke mindst hendes håndstilling er imidlertid ikonografisk velkendt og karakteriserer hende som orant, en bedende; berøringen af hendes kind kan være en velsignende gestus ligesom det klap på kinden, den katolske biskop endnu i dag tildeler de unge ved firmelsen.

"Der findes intet motiv i hele tapetet, som er mere gådefuldt," skrev A.E. Freeman, angelsaksisk histories grand old man (Freeman 1875, 708) om Ælfgyva-scenen. "Hvem er denne dame med et rent engelsk navn, som således pludselig indføres, øjensynligt ved porten til Vilhelms palads, åbenbart uden nogen reference til noget før eller senere ..." Freeman hælder til den teori, at kvinden er Harald Godwinsons yngre søster Ælfgifu, som ifølge Eadmer skulle være lovet en af Vilhelms riddere til ægte 


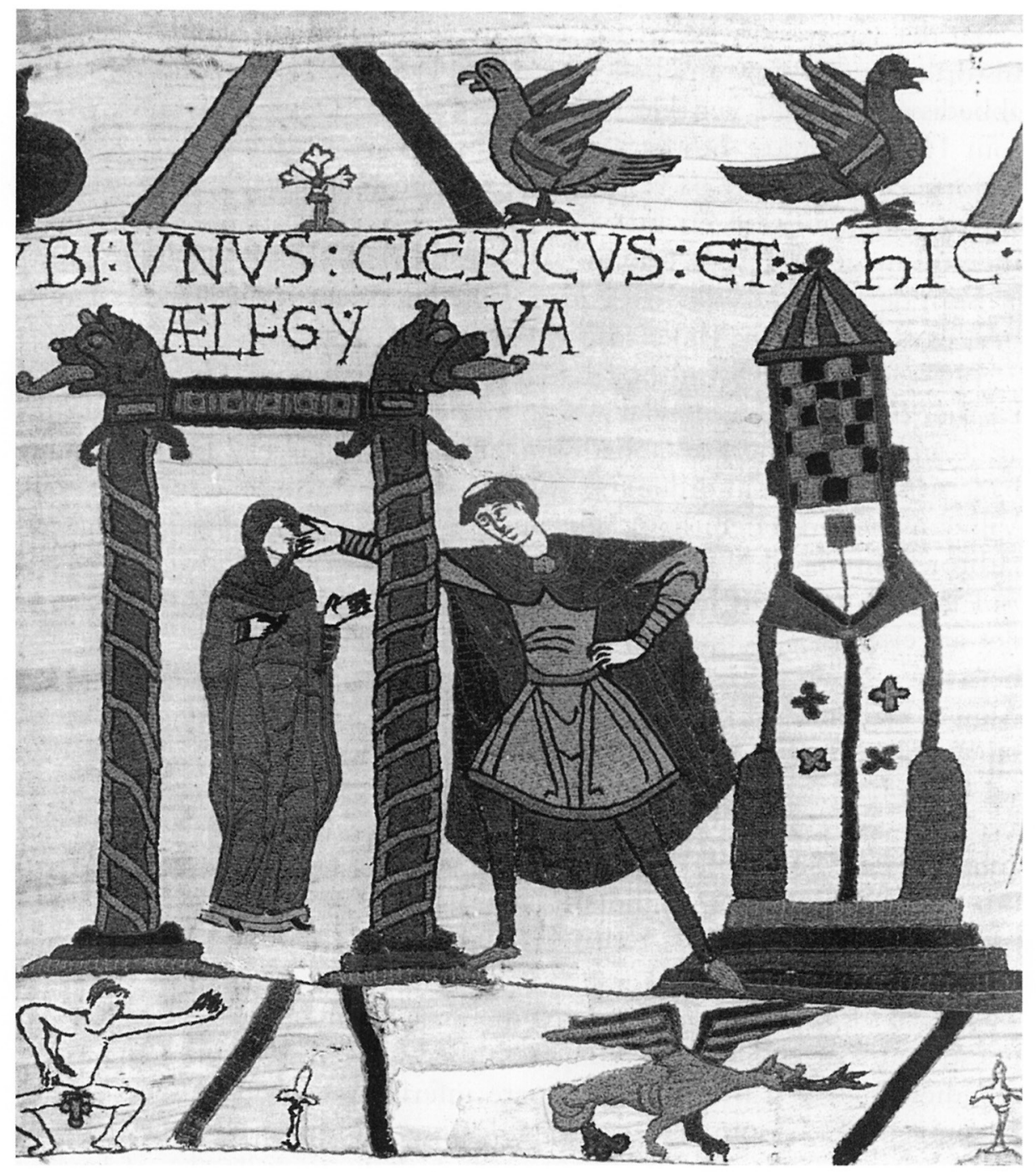

Fig. 7. Mange har gættet på, hvem den gådefulde Ælfgyva er, og hvorfor hun optræder på dette sted i Bayeux-tapetets beretning. Måske er hun Hakons mor, den tidligere abbedisse, der blev forført af Haralds bror.

Many have guessed who the mysterious Ælfgyva might be and why she appears at this place in the Bayeux Tapestry's narrative. Maybe she is Hakon's mother, the earlier abbess who was seduced by Harald's brother.

(Freeman 1875, 228). Men Eadmer fortæller også, at ordningen skulle besegles på et senere aftalt tidspunkt, når Harald ville sende sin søster til Vilhelm. Dette tyder ikke på, at hun allerede var til stede i Rouen. I øvrigt er det næppe en ung pige, vi ser, men en voksen kvinde. Freeman er selv tvivlende og konkluderer: "Enhver forklaring på denne gådefulde scene må blive rent gætteri ..." 
Ja, det står jo enhver frit for at gætte. Og for nogle år siden foreslog historikeren M.W. Campbell (Campbell 1984, 127-145), at kvinden er abbedissen Eadgifu ved klosteret i Leominster. Det var denne kvinde, som Haralds ældste broder, Svend, ifølge Den Angelsaksiske Krønike forførte eller bortførte på vej hjem fra et hærtog mod waliserne i 1046 og levede sammen med en tid. Svends søn, Hakon, kan efter Campbells mening meget vel være frugten af dette forhold. Svend var død samme år, som de to gidsler blev overladt i Vilhelms varetægt, og Hakon kan da have făet sin farbror Harald som værge.

Hvis Hakon var Svends og Eadgifus søn, ville han i 1052 have været ca. 5 år og i 1064-65, da Haralds ophold i Normandiet fandt sted, 17-18 år. Campbell mener, at abbedissen efter skandalen har måttet forlade både sit kloster og sin orden, og at hun har ledsaget sin lille søn til hertug Vilhelms hof i Rouen, hvor hun også selv er forblevet. Nu, da Hakons farbror kommer til Normandiet, er muligheden der for en frigivelse.

I tapetets indskrift hedder kvinden Ælfgyva, som er en latinisering af det angelsaksiske Ælfgifu - "den alfegivne" eller "den, som alferne har begavet". Navnet kendes i adskillige varianter: Alveva, Aleve, Elgive, Algiva. Eadgifu er ikke blandt disse, fordi det er et selvstændigt, velkendt pigenavn, som betyder "den, der er givet rigdom". Det er lidt ærgerligt for Campbell, at han må ty til den mulighed, at Bayeux-tapetets tekstforfatter har forvekslet de to almindelige navne. Imidlertid forekommer der andre skrive- og stavefejl i tapetet, og Campbell fastholder, at hans teori om Ælfgyvas identitet, sammenholdt med Eadmers redegørelse, er det hidtil bedste gxt.

Men hvis Ælfgyva er Eadgifu, hvem er så "unus clericus”? Måske en præst, som har indført den tidligere abbedisse ved hertughoffet i Normandiet. Han er i hvert fald en mere inferiør person end hun, som er navngivet. Det er som sagt næppe en lussing, han giver hende - det ville også nok være lidt sent at demonstrere kirkens misbilligelse af hendes mulige fejltrin i 1046.

Til sidst endnu et spørgsmål: Hvis præsten her blot ønsker Hakons mor held og lykke med hendes forsøg på at fă sønnen frigivet - eller lykønsker hende med, at Harald nu skaffer ham fri - hvad er så meningen med den obskøne mandsfigur nedenunder? Som før nævnt kan Bayeuxtapetets borter indeholde skjulte hentydninger til billedfrisens fortællinger. Kan figuren mon ikke henvise til den lidt for virile Svend og være et memento om hans forførelse af den smukke abbedisse for så mange år siden? 


\section{LITTERATUR}

Bernstein, 1). 1986: The Mystery' of the Bayeux Tapestry'. London 1986.

Bertrand, S. 1966: La tapisserie de Bayeux et la manière de vivre au onzième siècle. Bayeux 1966.

Campbell, M.W. 1984: Aelfgyva: The Mysterious Lady of the Bayeux Tapestry. Annales de Normandie 171984.

Eadmer ca. 1115: Historia Novorum in Anglia. - Eadmer's History of Recent Events in England. Transl. from the Latin by Geoffrey Bosanquet. London 1964. (Overs. fra engelsk i uddrag af M. Rud.

Freeman, A.E. 1875: The History' of the Norman Conquest of England III. (Oxford 1875.

Gotfredsen, L. \& H.J. Frederiksen. 1987: Troens Billeder. Forlaget Systime 1989.

Guillaume de Jumièges' og Guillaume de Poitiers' kroniker er citeret efter To Normanniske Kroniker, oversat af Erling Albrectsen. ()dense Universitetsforlag 1980.

Rud, M. 1994: Bayeux-tapetet og slaget ved Hastings 1066. 3. udg. København 1994.

Wissolik, R.I). 1979: The Saxon Statement: Code in the Bayeux Tapestry. Annale Mediaevale XIX. New Jersey 1979.

\section{A hidden Revelation in the Bayeux tapestry?}

\section{What was Harald Godwinson's purpose in Normandy?}

The Bayeux tapestry is a more than $9(0)$ year old, 7() meter long embroidery whose many pictures tell of events in Normany and England before and during the Battle of Hastings in 1066, when Duke William of Normandy won his famous epithet, the Conqueror. The long wall hanging is thought to have been made in England, perhaps in Canterbury, for William's halfbrother, Bishop Odo of Bayeux, and was completed for the consecration of Bayeux Cathedral in 1077. The tapestry is exhibited in Cenre Guillaume le Conquèrant in Bayeux.

The classical interpretation of the subject matter of the Bayeux tapestry is based on its own short Latin texts and contemporary descriptions in Norman chronicles (William of Juminèges and William of Poitier). According to these Harold Godwinson of Wessex traveled to Normandy in 1064 to confirm to Duke William on behalf of King Edward the Confessor the promise earlier given by the king to his relative William that he should inherit the crown of England after the death of the childless king (fig. 12).

After a number of dramatic events in which William and Harold give aid to one another, Earl Harold swears that he in due course will support the Duke in his demand (fig. 3). Harold returns home to meet the king (fig.4). The king dies and the earl allows himself to be declared king of England. In anger William gathers a fleet together, invades England, and defeats the English army at Hastings, where Harald falls.

However there is another explanation of Harold's journey. The English monk Eadmer relates in his chronicle, a History of Recent Events in England, which was written in Canterbury ca. 1115, that Harold asked his king for permission to go to Rouen in order to request duke William to free the earl's younger brother, Wulfnot, and his brother's son, Hakon, who had been William's hostages subsequent to a 
disagreement between the king and earl Godwin in 1(051. Eadmer writes that Harold was pressed by William to swear fealty and was therefore in his good right to break the oath after king Edward's death.

In recent years historians like $\mathrm{R}$.I). Wissolik and M.W. Campbell after close study of the tapestry have interpreted a number of details in support of Eadmer's version. Wissolik thinks for instance that the two small winged centaurs with child heads in the border (fig. 5) symbolize the hostages, who were children when they were given. $\mathrm{He}$ calls especial attention to the motif where Harold explains his errand to William. Behind the earl stands a young retainer who does not look like a Norman (fig. 6). The earl points at him or even touches his hand. Wissolik thinks that the young man is the hostage, Hakon. In the border under this motif is seen a man working on a large piece of wood with a broad axe. He hews or hacks, a verb that in Old English is haccian. Phonetically the word is close to the name Hakon.
When Harold returns home to king Edward, he is shown in the tapestry as a submissive and guilt conscious person who had risked England's future to achieve his own aims (fig. 4). The king, who according to Eadmer had advised strongly against the project, seems to be saying, I told you so!

Hakon was the son of Harold's elder brother, Swein, who died in the same year as the hostages were given. According to the Anglo-Saxon Chronicle Swein had had an affair with the abbess of Leominster. Is Hakon the outcome of this relationship, asks M.W. Campbell. I)id the abbess have to leave her religious house after the scandal, and did she accompany her little son to Normandy? Is it her in the scene Where a certain clerc and Ælfgyva (fig. 7)? Is the priest giving her a benevolent pat on the cheek the one who introduced her to the duke's court? Finally, is the naked male figure in the border meant to recall the abbess's mistake with the virile Swein many years earlier? 